\title{
Analysis of Cutting Conditions in the Process of Cross- cutting Wood by Circular Saws
}

\begin{abstract}
Ján Kováč,* Pavol Harvánek, Jozef Krilek,Tomáš Kuvik and Ján Melicherčík
An analysis was conducted of the effects of cutting conditions in the crosscutting of wood using circular saws. Gradual wear of the saw blade cutting wedges impacted the entire cutting process. Two different types of circular saw blades were used. One blade type featured sintered carbide tips and 54 saw blade teeth, whereas the other had high-speed steel with 56 teeth; both saw-blades were $600 \mathrm{~mm}$ in diameter with a rake angle of $20^{\circ}$. The two wood species were spruce (Picea abies) and beech (Fagus sylvatica). During sawing, the timber was fed at a velocity of $v_{f}=6$ and $12 \mathrm{~m} \cdot \mathrm{min}^{-1}$. The cutting speed $\left(v_{\mathrm{c}}\right)$ was set at $60 \mathrm{~m} \cdot \mathrm{s}^{-1}, 70 \mathrm{~m} \cdot \mathrm{s}^{-1}$ and $80 \mathrm{~m} \cdot \mathrm{s}^{-1}$. The saw blades were coated with three types of PVD coatings. The least energy intensive saw blade was a sintered carbide-free saw blade with a coating (AITiN) at a displacement speed of $12 \mathrm{~m} \cdot \mathrm{min}^{-1}$ and cutting speed of 60 $\mathrm{m} \cdot \mathrm{s}^{-1}$ with a power of $1310,63 \mathrm{~W}$. Any change of a saw blade considerably affected torque for all the wood species, so a particular type of saw blade will always have an impact on torque. Other parameters distinctively and individually influenced the process of wood sawing.
\end{abstract}

Keywords: Energy consumption; Cutting power; Saw blade; Cross-cutting

Contact information: The Technical University in Zvolen, Faculty of Technology, Department of Environmental and Forestry Machinery, T. G. Masaryka 24, 96053 Zvolen, Slovakia;

*Corresponding author: jan.kovac@tuzvo.sk

\section{INTRODUCTION}

The principal roles of the sawmill industry are the intensification of processing of wood as a raw material. Circular saws are widely used for wood cross-cutting. They are used to increase productivity and enhance the cut surface quality and reliability (Streklov 2015).

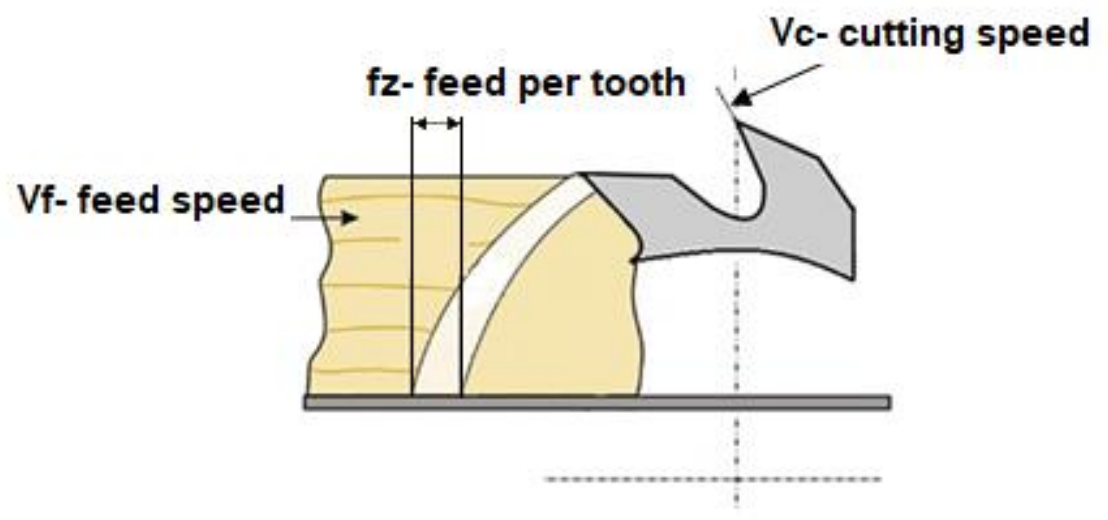

Fig. 1. Saw blade cutting kinematics (Author) 
Cutting wood by circular saw blades is a complex process. To achieve ideal operating conditions, it is important to know the mutual interactions among a tool, a product and influence of technical and technological factors affecting the cutting power and final quality of the product. It is possible to obtain the required quality by setting these factors and parameters. Cutting quality is affected by tool wear (Kminiak and Siklienka 2016; Siklienka et al. 2017; Krilek et al. 2020). Saw blade cutting kinematics are shown in Fig. 1.

Cross-cutting saw blades are frequently used in sawmills to cut round timber, balks, and boards. Such machines are called circular saws or mitre saws. Svoreň (2002) divides cross-cutting operations into two types: preliminary cross-cutting with oversize dimensions and final cross-cutting to the required dimensions.

The crucial cutting tool in the process of cross-cutting is the rotating blade that cuts perpendicularly to wood fibres. The minor teeth cutting edges on the sides of a blade cut through the fibres and form the walls of a kerf. The bottom of the kerf is shaped by the main cutting edges (Lisičan 1982). These cutting edges are most commonly made with sintered-carbide plates, which are referred to as HW plates or tool steel (Banski 2000; Siklienka et al. 2012;). Saw blades with HW plates (HW means carbide plates) are more durable and wear-resistant than blades made of tool steel (high-speed steel HSS) (Suchanov 1984). The parameters of the process of wood cutting (energy consumption, dust, and noise), parameters of the worked product (dimensional accuracy and quality of the surface), and the parameters of the particles produced within the process (size and granulometric composition) (Table 1) are largely dependent on the durability of the blade teeth (Streklov 2015).

Table 1. Criteria Influencing the Process of Cutting (Mikleš et al. 2010)

\begin{tabular}{|c|c|c|c|}
\hline Criteria & Workpiece & Machine & Tool \\
\hline External & $\begin{array}{c}\text { Uncut chips cross section' } \\
\text { and depth and quality of } \\
\text { kerf }\end{array}$ & $\begin{array}{c}\text { Feed rate, cutting forces, } \\
\text { cutting speed, vibration, } \\
\text { durability, and cutting } \\
\text { power }\end{array}$ & $\begin{array}{c}\text { Wear and cutting } \\
\text { edge geometry }\end{array}$ \\
\hline $\begin{array}{c}\text { Wood species, wood } \\
\text { strength, cutting direction } \\
\text { towards fibres, moisture } \\
\text { content, and wood } \\
\text { density }\end{array}$ & $\begin{array}{c}\text { Properties of material and } \\
\text { type of material }\end{array}$ & $\begin{array}{c}\text { Properties of material } \\
\text { and type of material }\end{array}$ \\
\hline
\end{tabular}

According to several studies (Orlicz 1988; Orlowski et al. 2006; Orlowski 2007; Scholz et al. 2009; Naylor et al. 2012), the hardness of the material and the friction between the blade and workpiece are the most important parameters with respect to the particular saw blade tooth geometry. Recent work focusing on cutting mechanics (Atkins 2009; Kopecký and Hlásková 2014; Orlowski et al. 2014, 2020) found that the crack resistance of a workpiece (fracture toughness) is of equal importance to force and friction when determining the force and reducing the action of forces.

The wood cutting parameters (energy consumption, dust level, and noise level), the emerging product parameters (dimensional accuracy and created surface quality), and the produced chip parameters (dimensions and particle size composition) depend on the teeth shape, teeth dimensions and number, cutting tool geometry, sharpness, and technological conditions of the process, such as feed speed, feed force, and cutting speed (Barcík and 
Gašparík 2014; Krilek et al. 2014; Gaff et al. 2015; Kvietková et al. 2015; Gaff et al. 2016; Kminiak and Kubš 2016).

A fundamental role, when sawing, is played by the blade perpendicular to the direction of the wood fibers. During transversal cutting, the lateral cutting edges of the saw blade teeth cut the fibers and form the walls of the cut kerf (Fig. 2b). The main cut edges during closed cutting form the gullet bottom. A typical feature of a surface created by sawing with saw blades are half-moon-shaped traces (Fig. 2a) (Kminiak and Gaff 2015).

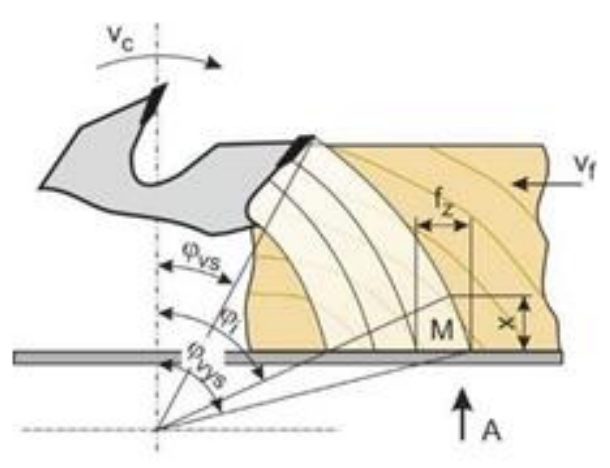

A

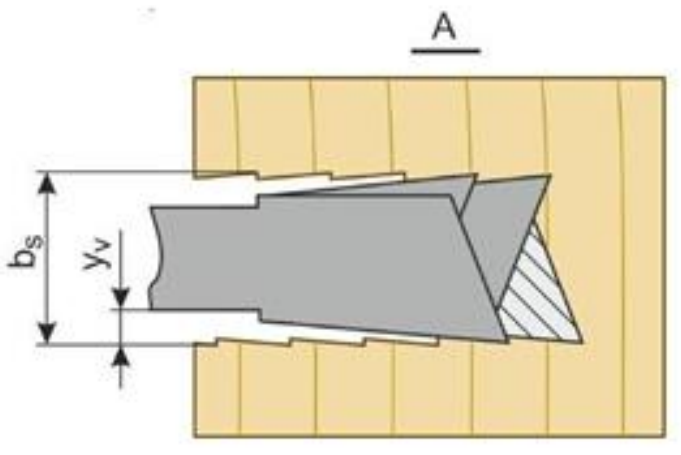

B

Fig. 2. Mechanism of cut surface creation by sawing: $A$ half-moon shaped traces, and $B$ forming of cut kerf. (Note: $v c$ denotes cutting speed, vf feed speed, $f z$ feed per tooth $\varphi v s$ feed angle of the cutting edge entry into the wood, $\varphi v y s$ feed angle of the cutting edge exit from the wood, $\varphi$ i feed local angle corresponding to the monitored point $\mathrm{M}, b s$ cut gap width, and $y v$ saw teeth setting). Copyright publishing illustrations we received from authors (Kminiak and Gaff 2015).

The widespread approach to determining the cutting power in a cutting process is by use of a model based on the specific cutting resistance $k_{\mathrm{c}}$. Thus, the cutting power could be determined as (Orlowski et al. 2020),

$$
P_{c}=F_{C} \cdot v_{C}=k_{C} \cdot A_{D a v} \cdot v_{C}=k_{c} \cdot S_{t} \cdot h_{A V} \cdot v_{C}
$$

where $k_{\mathrm{c}}$ is specific cutting resistance in $\left(\mathrm{N} . \mathrm{mm}^{-2}\right), P_{\mathrm{c}}$ is cutting power in $(\mathrm{W}), F_{\mathrm{c}}$ is cutting force in (N), ADav is the average cross-sectional area of uncut chip in $\left(\mathrm{mm}^{2}\right), v_{c}$ is cutting speed in $\left(\mathrm{m} . \mathrm{s}^{-1}\right), S_{\mathrm{t}}$ is the overall set (kerf) in $(\mathrm{mm})$, and $h_{\mathrm{av}}$ is the average uncut chip thickness in $(\mathrm{mm})$.

The power $(P)$ can also be calculated by deriving the relation to the torque calculation using the spindle speed,

$P_{C}=\frac{M_{K} \cdot n}{9550}$

where $P_{\mathrm{c}}$ is power $(\mathrm{kW}), M_{\mathrm{k}}$ is torque $(\mathrm{N} \cdot \mathrm{m})$, and $n$ is speed $(\mathrm{rpm})$.

The selection of adequate tools with a suitable cutting edge geometry and appropriate cutting conditions can reduce costs associated with sawing wood and thus increase the overall efficiency and cutting accuracy of the process. The energy intensity of the sawing process is commonly defined in terms of cutting output power (Siklienka et al. 2013). As specified by STN ISO 3002-4 (1995), the cutting output power defined as $k_{\mathrm{c}}$ indicates the difficulty of the cutting process and depends on various factors that determine cutting conditions, which include technical (influence of cutting parameters and tools) and 
technological parameters (cutting properties of the material). Because wood is an anisotropic material, and its properties vary at different sections of a tree trunk, the theoretical determination of $k_{\mathrm{c}}$ may be considerably complex and inaccurate (Skutko 2004; Siklienka and Mišura 2006).

Coating is used for improvement of saw blade properties in the wood-cutting process. Creation of thin isotropic coating on the functional surfaces of the cutting edge, for instance, can be a highly effective way for improvement of cutting material properties. Different properties for realization of processes evoke the need for a wider range of cutting materials with different chemical, physical, mechanical, and technological properties. (Hrubec 1990, 1988).

\section{EXPERIMENT}

The goal of the work was to use theoretical knowledge to prepare an experiment and to find the influence of saw blade coating on energetic consumption and parameters of wood cross-cutting. In practice this means to find values of torque on the crankshaft of the experimental device with respect to the course of frequency of revolutions in the specified conditions and finally to evaluate the results. The chemical composition of coating used in the process of coating by PVD method (i.e. Physical Vapour Deposition) was AlTiN, AlTiCrN, and AlTiCrSiN. These coatings were chosen on the basis of recommendations of producers, and they have been used for a very long time in practice. It was the same with cutting parameters (i.e. cutting speed, feed speed, type of saw blades, wood), which were chosen on the basis of previous experiments, measurements, and calculations.

\section{Materials}

The measurements of wood cross-cutting were taken on the testing machine (Fig. 3). All measurements of the cutting conditions were obtained from the Stend testing machine. The experimental device was designed, constructed, and further developed at the Department of Environmental and Forestry Machinery and in the workshops of the Technical University in Zvolen (Zvolen, Slovakia). The testing machine was composed of two main members, which included the feeding system and the cutting system.

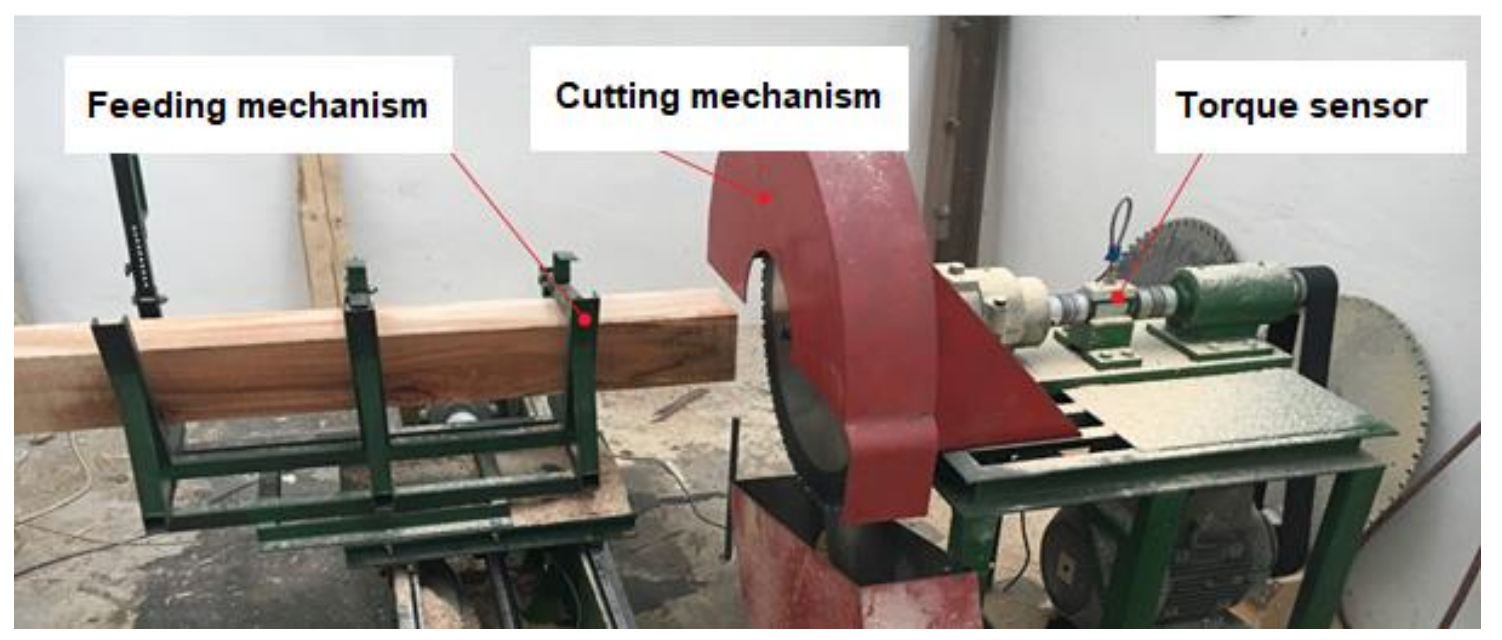

Fig. 3. Experimental device 
The force and action of torque was transferred onto the saw blade via the cutting system (cutting mechanism). The sliding member ensured safe clamping and feeding of the workpiece. The test equipment (Fig. 3) consisted of a feeding mechanism, cutting mechanism, and a three-phase asynchronous motor with an output of $7.5 \mathrm{~kW}$. The torque was transmitted through the belt of a safety coupling GIFLEX GFLL - 28 (Hottinger Baldwin Messtechnik GmbH T20WN, Darmstadt, Germany), an input coupling of the torque sensor (Hottinger Baldwin Messtechnik GmbH T20WN, Darmstadt, Germany), the output coupling of the torque sensor, and a saw-blade spindle head.

\section{Test Samples}

The measurements were performed on the samples of spruce wood (Picea abies) (Technical University in Zvolen, Forestry Industry Zvolen, Zvolen, Slovakia) and beech wood (Fagus sylvatica) (Technical University in Zvolen, Forestry Industry Zvolen, Zvolen, Slovakia) with the dimensions of $200 \mathrm{~mm} \times 200 \mathrm{~mm} \times 1000 \mathrm{~mm}$. The dimensions were selected based on the technical parameters of the testing machine.

Moisture readings were obtained via gravimetric analysis, which is a direct method to measure wood moisture by weight measurement. The principle of this method lies in evaluating a weight difference between wet and dry timber. Drying took place at $103{ }^{\circ} \mathrm{C} \pm$ $2{ }^{\circ} \mathrm{C}$ in a MEMMERT UNB 200 drying oven (MEMMERT GmbH+Co.KG, Schwabach, Germany). The measurements of wood moisture are listed in Table 2.

Table 2. Moisture Content

\begin{tabular}{|c|c|}
\hline $\begin{array}{c}\text { Wood } \\
\text { Species }\end{array}$ & Moisture Content (\%) \\
\hline Beech & 61.22 \\
\hline Spruce & 46.91 \\
\hline
\end{tabular}

\section{Saw Blades}

The saw blades had the same cutting tooth geometry but different cutting tooth structures. The samples were cut by circular saws made with cemented carbide plates and of high-speed steel (their technical parameters are shown in Table 3).

Table 3. Basic Dimensions of Circular Saws

\begin{tabular}{|l|c|c|c|c|c|}
\hline Basic dimensions & $\begin{array}{c}\text { Diameter } \\
\text { of a saw } \\
\mathbf{D}(\mathbf{m m})\end{array}$ & $\begin{array}{c}\text { Width of } \\
\text { a saw } \\
\mathbf{B}(\mathbf{m m})\end{array}$ & $\begin{array}{c}\text { Cutting- } \\
\text { clearance } \\
\text { angle } \\
\mathbf{\alpha}\left({ }^{\circ}\right)\end{array}$ & $\begin{array}{c}\text { Cutting- } \\
\text { edge side } \\
\text { rake } \\
\left.\mathbf{(}^{\circ}\right)\end{array}$ & $\begin{array}{c}\text { No. of } \\
\text { teeth }\end{array}$ \\
\hline $\begin{array}{l}\text { Circular saw made } \\
\text { of high-speed steel }\end{array}$ & 600 & 5.4 & 20 & $-5,0,5,10$ & 56 \\
\hline $\begin{array}{l}\text { Circular saw made } \\
\text { with cemented } \\
\text { carbide plates }\end{array}$ & 600 & 5.4 & 15 & $\begin{array}{c}-10,0,10, \\
20\end{array}$ & 54 \\
\hline
\end{tabular}

One pair of saw blades (HSS, sintered carbide) was without coating, the second pair of saw blades was coated by PVD coat MAXIMIZER AlTiN (HSS_M, sintered carbide_M), the third pair of saw blades was coated by PVD coat CRONAL I. AlTiCrSiN (HSS_C_I, sintered carbide_C_I). 
PVD coat MAXIMIZER (M) is on the basis of aluminium-titanium-nitrogen (AlTiN). It is suitable for medium cutting speed. The producer indicates $f_{\mathrm{t}}=0.6$ as a frictional coefficient. Coat AlTiN was spread for the temperature $500{ }^{\circ} \mathrm{C}$. The frictional coefficient was 0.6 . The thermal resistance is generated by the friction of the working surfaces of the wood cutting process was $800{ }^{\circ} \mathrm{C}$.

PVD coat CRONAL I. (C_I) is on the basis aluminium-titanium-chromium-siliconnitrogen (AlTiCrSiN). It is resistant to wearing. PVD coat CRONAL I. has of high content of chromium $(\mathrm{Cr})$. It is especially designed for extreme cutting conditions in processing of hard materials. AlTiCrSiN coat was spread for temperature up to $500{ }^{\circ} \mathrm{C}$. The frictional coefficient is 0.45 . The thermal resistance in the cutting process when using another material reaches a temperature of up to $1,000{ }^{\circ} \mathrm{C}$.

PVD coat KTRN I. (K_I) is on the basis of aluminium-titanium-chromium-nitrogen (AlTiCrN). It is resistant to high temperatures and wearing. PVD coat KTRN is suitable for application where chemical and thermal resistance are required. AlTiCrN coat is spread up to temperature of $500{ }^{\circ} \mathrm{C}$. The frictional coefficient is 0.45 .

\section{Measuring Procedure}

The experiment was performed by comparing two saw blades at different feeding speeds $\left(v_{\mathrm{f}}=6 \mathrm{~m} \cdot \mathrm{min}^{-1}\right.$ and $\left.12 \mathrm{~m} \cdot \mathrm{min}^{-1}\right)$, rotational speeds $\left(\mathrm{n}=1900 \mathrm{~min}^{-1}, 2230 \mathrm{~min}^{-1}\right.$, and $\left.2550 \mathrm{~min}^{-1}\right)$, and cutting speeds $\left(v_{\mathrm{c}}=60 \mathrm{~m} \cdot \mathrm{s}^{-1}, 70 \mathrm{~m} \cdot \mathrm{s}^{-1}\right.$, and $\left.80 \mathrm{~m} \cdot \mathrm{s}^{-1}\right)$. The samples of beech wood and spruce wood were used. Each measurement was repeated several times to acquire adequate statistical significance. The samples were placed $50 \mathrm{~mm}$ below the axis of the spindle. The outcome of the experiment indicated the large influence of torque on the cutting process. The torque was measured by a HBM T20WN torque sensor (Hottinger Baldwin Messtechnik GmbH T20WN, Darmstadt, Germany), and a SPIDER8 electronic measurement system (Hottinger Baldwin Messtechnik GmbH T20WN, Darmstadt, Germany) was used for measurement of the mechanical quantities. The results were processed and evaluated using STATISTICA 12 software (DataFriends, s.r.o., vesion 12, Plzeň, Czech Republic).

\section{RESULTS AND DISCUSSION}

The aim of the measurements was to determine the extent to which changing factors such as cutting speed, saw blade type, wood species, and feeding speed, affect the amount of torque (cutting power) in the process of wood cutting.

On the basis of significance level (Table 3) and multifactorial analysis (ANOVA) of measured values it is a clearly visible influence of all factors and their interactions. From Table 3, in the case of spruce wood, the change in rotation speed had no effect on the torque and thus on the cutting power of the sintered carbide saw blade. Except in one case, the change in rotation speed did not affect the cutting performance of the high-speed saw blades. However, the results for beech samples were not so clear. The change in speed in most cases affected the cutting performance. Both spruce and beech wood samples affected the cutting performance by changing the feed rate observed with the high-speed saw blade and the saw blade with sintered carbide inserts. The type of saw blade used affected the cutting force of all woods, the feed rate and the rotation speed. Other parameters affect the type of wood, such as the feed rate, which is more observable at higher speeds. 
Table 3. Basic Table of Multifactor Analysis of Power for Saw Blade, Wood, Feed and Cutting Speed

\begin{tabular}{|c|c|c|c|c|c|}
\hline Effect & $\begin{array}{l}\text { Sum of } \\
\text { squares }\end{array}$ & $\begin{array}{l}\text { Degree of } \\
\text { freedom }\end{array}$ & $\begin{array}{c}\text { Sample of } \\
\text { variance }\end{array}$ & F-test & $\begin{array}{c}\text { p-value } \\
\text { (sign. level) }\end{array}$ \\
\hline Overall average & $6.16410 \mathrm{E}+09$ & 1 & $6.164104 \mathrm{E}+09$ & 2559047 & 0.000000 \\
\hline Wood & $1.61793 \mathrm{E}+04$ & 1 & $1.617926 \mathrm{E}+04$ & 7 & 0.009696 \\
\hline Saw blade & $8.30450 \mathrm{E}+07$ & 7 & $1.186356 \mathrm{E}+07$ & 4925 & 0.000000 \\
\hline$v_{f}$ & $1.57358 \mathrm{E}+06$ & 3 & $5.245258 \mathrm{E}+05$ & 218 & 0.000000 \\
\hline$v_{\mathrm{c}}$ & $1.26214 \mathrm{E}+08$ & 2 & $6.310716 \mathrm{E}+07$ & 26199 & 0.000000 \\
\hline Wood* Saw blade & $2.43738 E+06$ & 7 & $3.481973 E+05$ & 145 & 0.000000 \\
\hline Wood $^{*} V_{f}$ & $2.82974 \mathrm{E}+05$ & 3 & $9.432451 E+04$ & 39 & 0.000000 \\
\hline Saw blade $V_{f}$ & $7.71179 E+06$ & 21 & $3.672282 \mathrm{E}+05$ & 152 & 0.000000 \\
\hline Wood $^{*} v_{\mathrm{c}}$ & $1.97527 \mathrm{E}+04$ & 2 & $9.876362 E+03$ & 4 & 0.016860 \\
\hline Saw blade ${ }^{*} v_{c}$ & $9.13491 E+05$ & 14 & $6.524935 E+04$ & 27 & 0.000000 \\
\hline$v f^{*} v_{\mathrm{c}}$ & $7.94450 \mathrm{E}+04$ & 6 & $1.324083 E+04$ & 5 & 0.000013 \\
\hline $\begin{array}{r}\text { Wood }{ }^{*} \text { Saw } \\
\text { blade }^{*} V_{\dagger}\end{array}$ & $2.74159 E+06$ & 21 & $1.305520 \mathrm{E}+05$ & 54 & 0.000000 \\
\hline $\begin{array}{r}\text { Wood }{ }^{*} \text { Saw } \\
\text { blade }^{*} v_{c}\end{array}$ & $3.69769 \mathrm{E}+05$ & 14 & $2.641210 \mathrm{E}+04$ & 11 & 0.000000 \\
\hline Wood $^{*} V_{\mathrm{f}}^{*} V_{\mathrm{c}}$ & $1.49015 E+05$ & 6 & $2.483582 E+04$ & 10 & 0.000000 \\
\hline Saw blade ${ }^{*} V_{\mathrm{f}}^{*} V_{\mathrm{c}}$ & $1.01259 E+06$ & 42 & $2.410928 \mathrm{E}+04$ & 10 & 0.000000 \\
\hline $\begin{array}{l}\text { Wood }{ }^{*} \text { Saw } \\
\text { blade }^{*} V_{\mathrm{f}}^{*} v_{\mathrm{c}}\end{array}$ & 8.46919E+05 & 42 & $2.016474 \mathrm{E}+04$ & 8 & 0.000000 \\
\hline Error & $2.31240 E+06$ & 960 & $2.408750 \mathrm{E}+03$ & & \\
\hline
\end{tabular}

The cutting power increased with increasing cutting speed and it is also possible to see the difference between the saw blades on the graph of 95\% confidence interval (Fig. 4). M-coated saw blades had lower energy consumption than other coatings and uncoated saw blades.

The results obtained are shown in Fig. 5 where the difference between the torque of the sawing of spruce wood and the sawing of beech wood was apparent.

In Figs. 6, 7, and 8 there are presented results of 95\% confidence interval for mean power values depending on saw blades, wood and cutting feed speed. With increasing cutting speed there is also increased energetic consumption. The significant difference in performance is in case of coated and uncoated saw blades except the saw blade with coating MAXIMIZER (M) where the performance was the lowest.

This study was built on previous findings by Siklienka et al. (2013) and Krílek et al. (2014), which was why saw blades with a $20^{\circ}$ cutting edge angle were selected, as previous research indicated that they were most effective.

In cutting with HSS steel saw blades, the progress of Cutting Power was defined by a rapid increase until reaching the maximum value, which was followed by mild decline and then a rapid decrease. The rapid decline was caused by the end of the wood cutting operation. The same results were obtained by Kováč and Mikleš (2009). 


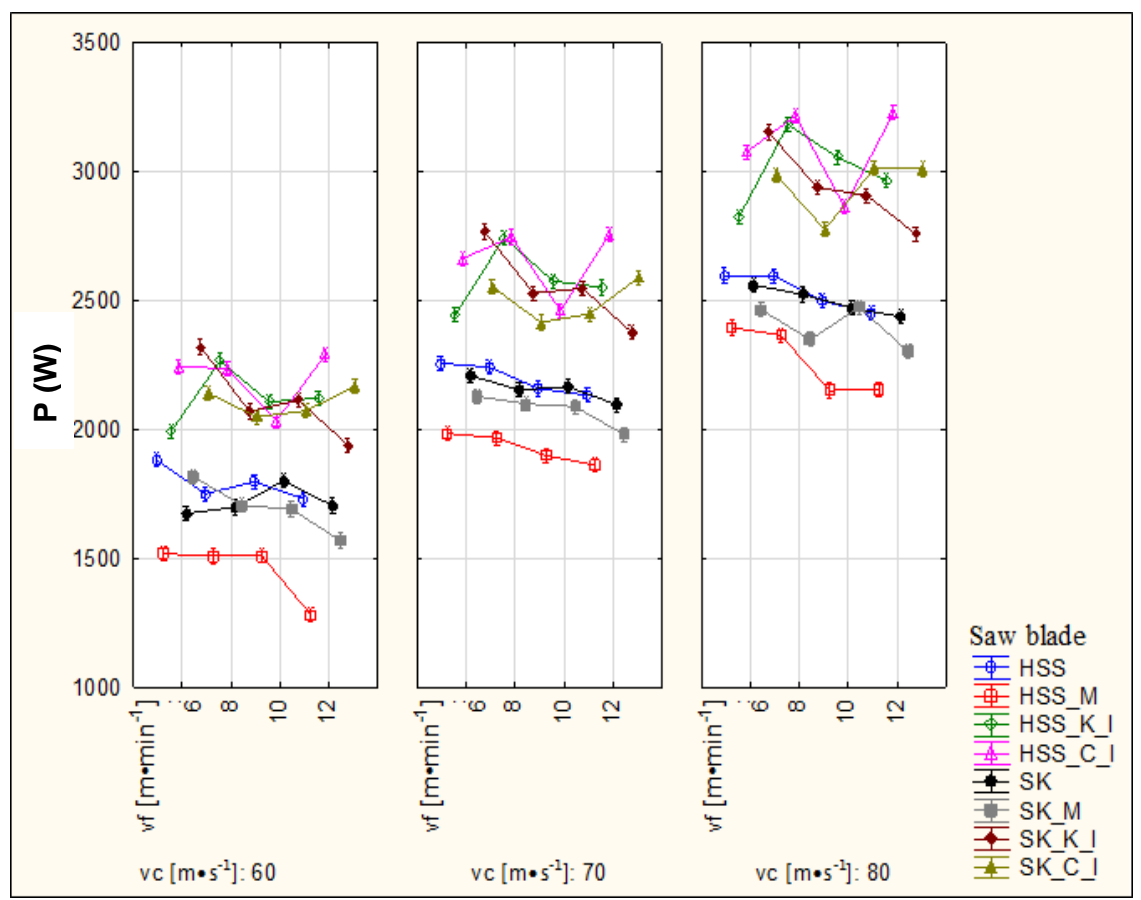

Fig. 4. 95\% confidence interval for mean power values depending on saw blades, cutting and feed speed

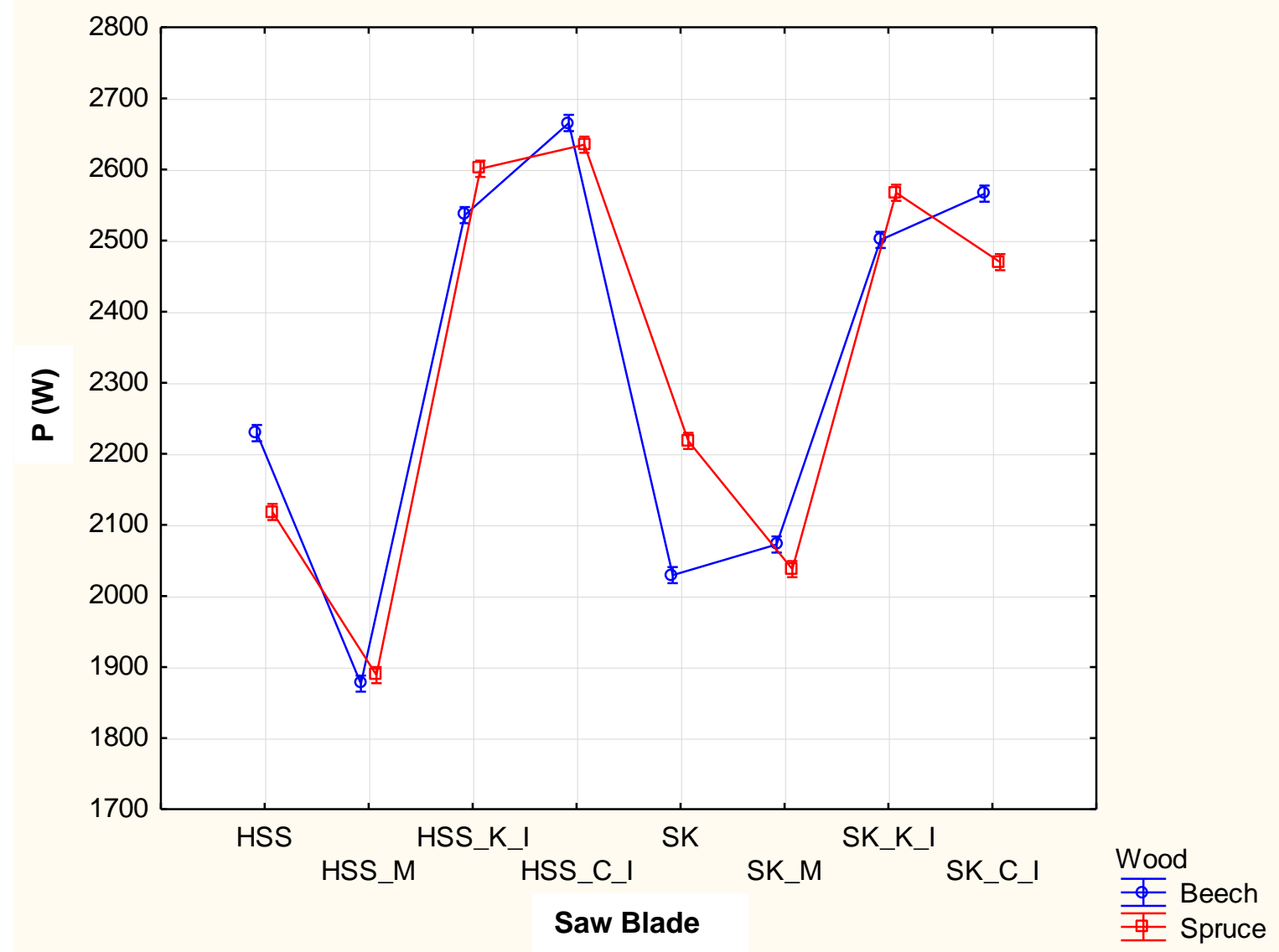

Fig. 5. 95\% confidence interval for mean power values depending on saw blades and wood 


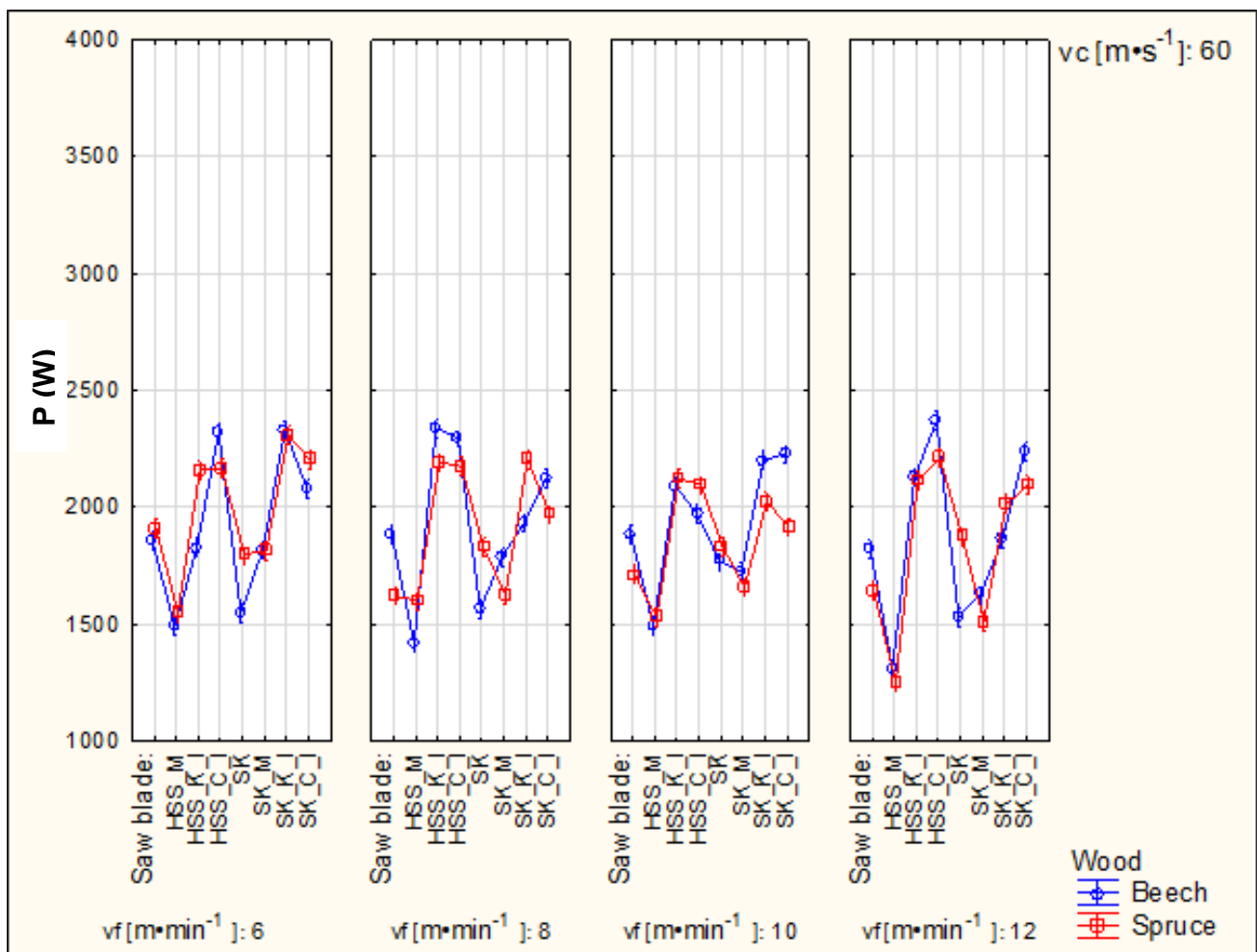

Fig. 6. 95\% confidence interval for mean power values depending on saw blades, wood, cutting feed speed $\left(v_{\mathrm{c}}=60 \mathrm{~m} \cdot \mathrm{s}^{-1}\right)$

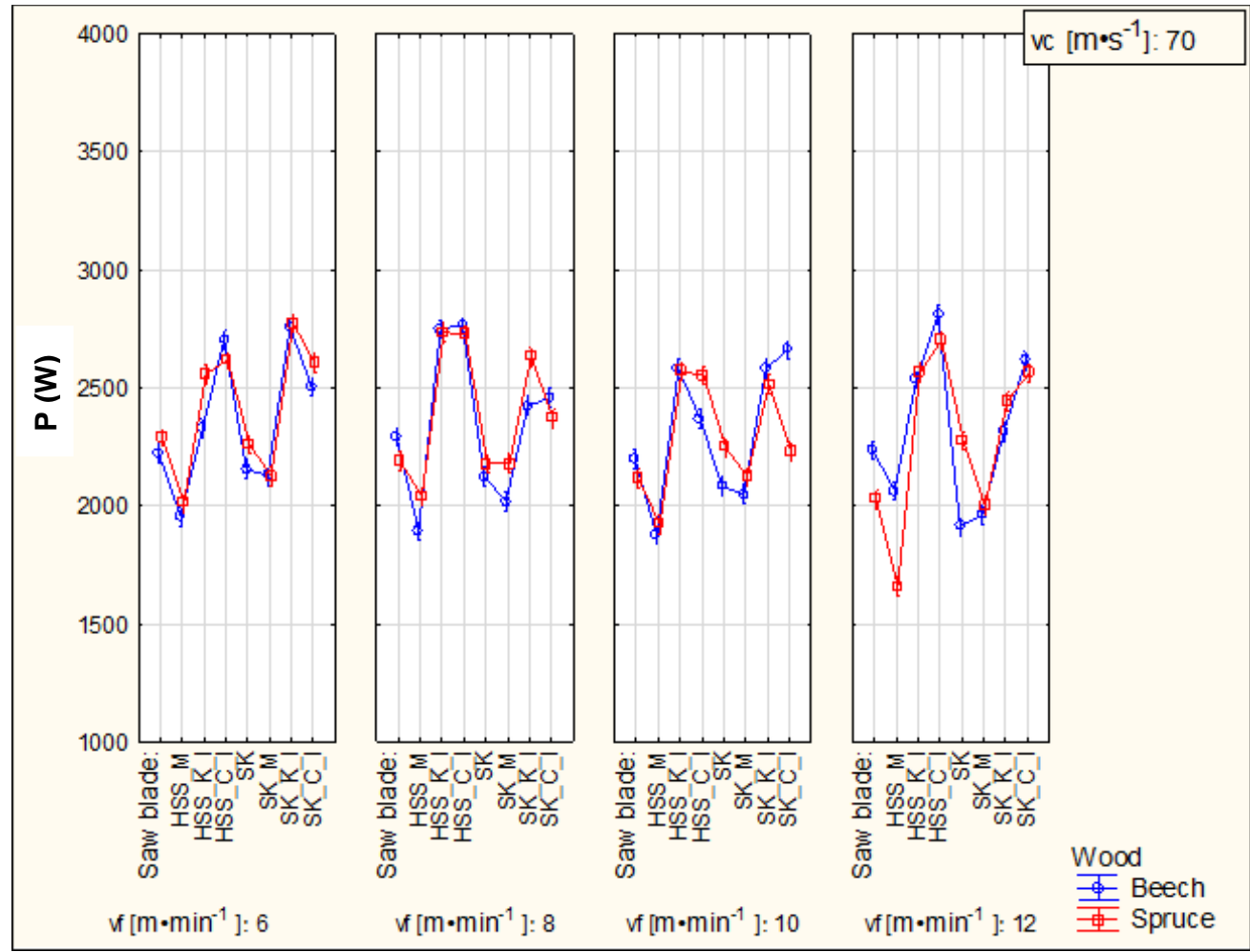

Fig. 7. 95\% confidence interval for mean power values depending on saw blades, wood, cutting feed speed $\left(v_{\mathrm{c}}=70 \mathrm{~m} \cdot \mathrm{s}^{-1}\right)$ 


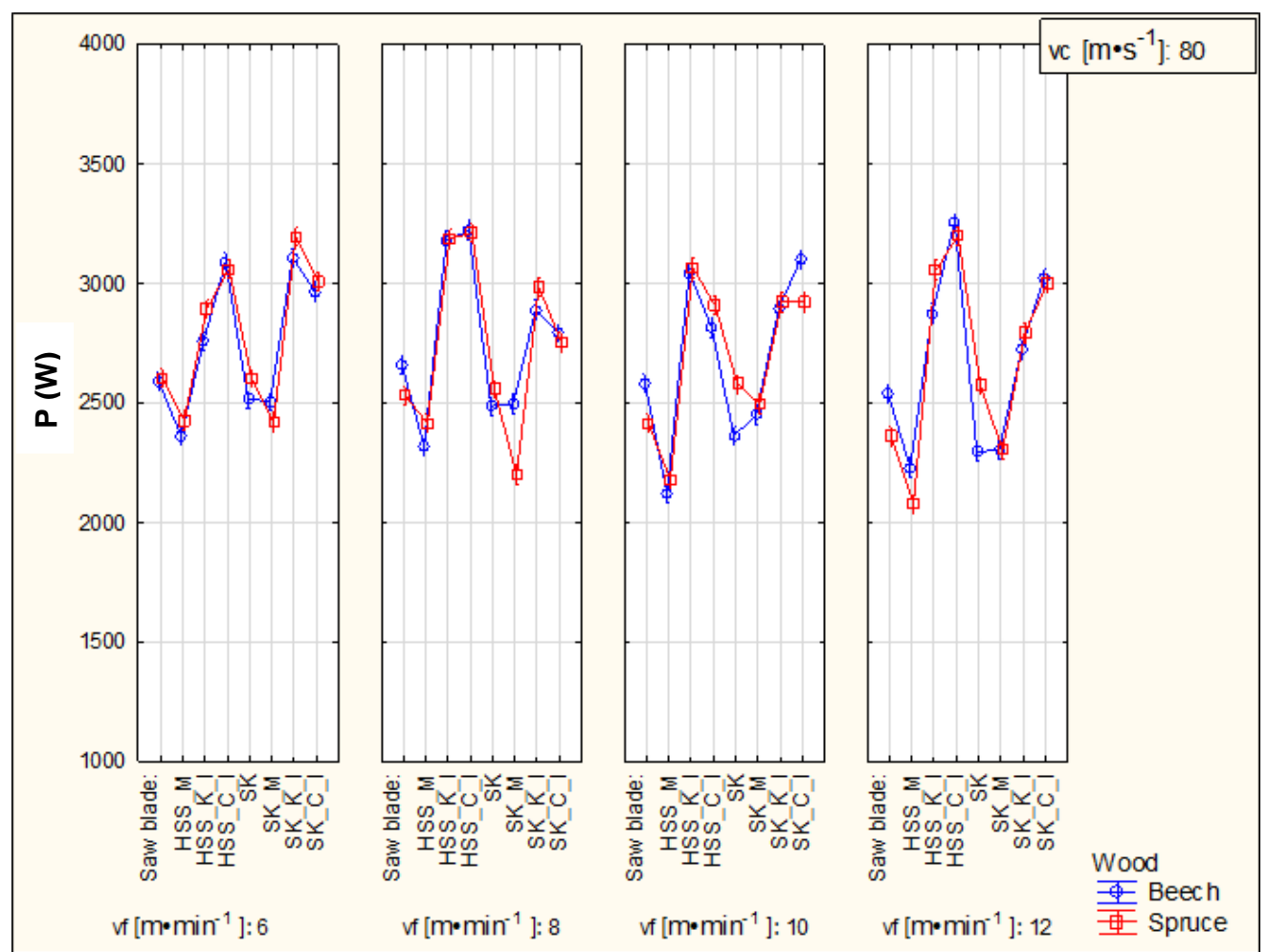

Fig. 8. 95\% confidence interval for mean power values depending on saw blades, wood, cutting feed speed $\left(v_{\mathrm{c}}=80 \mathrm{~m} \cdot \mathrm{s}^{-1}\right)$

Based on the change of the input factors that interacted in the cutting process (feed speed $(\nu \mathrm{f})$, minimum overhang, and type of circular saw blade), feed rate $(\nu \mathrm{f})$ appeared to be the most important determinant of energy performance in the cutting process and thus cutting input power. From the measured values, it can be noted that the PVD coating MAXIMIZER (AITiN) had a positive effect on the energy intensity of the wood cutting process and reduced the magnitude of the cutting power when sawing beech and spruce trees. PVD coatings KTRN I. (AlTiCrN) and CRONAL I. (AlTiCrSiN) did not show a positive effect on the cross-cutting process of wood and increase the energy intensity of the process. The authors think this is due to the surface treatment process, which was different from the MAXIMIZER surface treatment, and its treatment could improve the resulting performance values.

\section{CONCLUSIONS}

1. The possibility of verifying the calculation of the torque and construction of the teeth of the saw blades had a fundamental impact on the energy intensity of the production of different types of wood.

2. The least energy-intensive saw blade was a saw blade without sintered carbide with a surface treatment (AlTiN), for sawing beech wood.

3. The least energy intensive saw blade is a sintered carbide-free saw blade with a coating $(\mathrm{AlTiN})$ 
4. The conditions under which the experiments were performed mimicked real-world conditions. Therefore, it was possible to compare the results of this study with those of other research institutions.

\section{ACKNOWLEDGMENTS}

This article was produced as a part of Project VEGA (No. 1/0642/18): “Analysis of the Impacts of Constructional Parts of Forest Mechanisms in the Forestry Environment with regard to Energetic and Ecological Demands," of the Technical University in Zvolen (Slovakia).

\section{REFERENCES CITED}

Atkins, A. G. (2009). The Science and Engineering of Cutting: The Mechanics and Process of Separating, Scratching and Puncturing Biomaterials, Metals and Nonmetals, Butterworth-Heinemann, Oxford, England.

Banski, A. (2000). "Maintenance of saw blades with sintered carbides," in: Wood Cutting Tools, Care and Safety at Work, Zvolen Technical University, Zvolen, Slovakia, pp. 76-85. (In Slovak)

Barcík, Š., and Gašparík, M. (2014). "Effect of tool and milling parameters on the size distribution of splinters of planed native and thermally modified beech wood," BioResources 9(1), 1346-1360. DOI: 10.15376/biores.9.1.1346-1360

Gaff, M., Kvietková, M., Gašparík, M., Kaplan, L., and Barcík, Š. (2015). "Effect of selected parameters on the surface waviness in plane milling of thermally modified birch wood," BioResources 10(4), 7618-7626. DOI: 10.15376/biores.10.4.7618-7626

Gaff, M., Sarvašová-Kvietková, M., Gašparík, M., and Slávik, M. (2016). “Dependence of roughness change and crack formation on parameters of wood surface embossing," Wood Research 61(1), 163-174.

Hrubec, J. (1988). Technology for Processing, Bratislava: Publisher SVŠT, 1988. (In Slovak)

Hrubec, J. (1990). Special Technology II. Bratislava: Publisher SVŠT, 1990. ISBN 80227-0465-2. (In Slovak)

Kminiak, R., and Gaff, M. (2015). "Roughness of surface created by transversal sawing of spruce, beech, and oak wood," BioResources 10(2), 2873-2887.

Kminiak, R., and Kubš, J. (2016). "Cutting power during cross-cutting of selected wood species with a circular saw," BioResources 11(4), 10528-10539.

Kminiak, R., and Siklienka, M. (2016). "Influence of the saw blade design on the cutting performance in the cross cutting of beech lumber on a circular saw blade with manual feed to the cut," Chip and Chipless Woodworking Processes 10(1), 91-99. (In Slovak)

Kováč, J., and Mikleš, M. (2009). “The impact of selected parameters on the energy intensity of sawing wood cutting process," (http://www.fvt.tuke.sk/journal/pdf09/3str-23-26.pdf) Accessed 20 Sept 2015. (In Slovak) 
Kopecký, Z., and Hlásková, L. (2014). “An innovative approach to prediction energetic effects of wood cutting process with circular-saw blades," Wood Research 59(5), 827-834.

Krilek, J., Kováč. J., and Kučera, M. (2014). "Wood crosscutting process analysis for circular saws," BioResources 9(1), 1417-1429. DOI: 10.15376/biores.9.1.1417-1429

Krilek, J., Ťavodová, M., Kováč, J., and Tichý, B. (2020). "Impact of irregular tooth pitch of circular saw blades on power for wood cross-cutting," in: Drvna Industrija: Znanstveni Časopis za Pitanja Drvne Technologije. 71(1), 3-11.

Kvietková, M., Gaff, M., Gašparík, M., Kminiak, R., and Kriš, A. (2015). "Effect of number of saw blade teeth on noise level and lifetime of blade edges during cutting of wood," BioResources 10(1), 1657-1666. DOI: 10.15376/biores.10.1.1657-1666

Lisičan, J. (1982). Fundamentals of Machining and Division of Wood Materials, VŠLD, Zvolen, Slovakia. (In Slovak)

Mikleš, M., Kováč, J., and Krilek, J. (2010). Research of Cutting Conditions of Cross Cutting Wood, Technical University in Zvolen, Zvolen, Slovakia. (In Slovak)

Naylor, A., Hackney, P., Perera, N., and Clahr, E. (2012). "A predictive model for the cutting force in wood machining developed using mechanical properties," BioResources 7(3), 2883-2894. DOI: 10.15376/biores.7.3.2883-2894

Orlicz, T. (1988). Wood Machining with Cutting Tools, Skrypty SGGW-AR w Warszawie, Wydawnictwo SGGW-AR, Warsaw, Poland. (In Polish)

Orlowski, K. (2007). "Experimental studies on specific cutting resistance while cutting with narrow-kerf saws," Advances in Manufacturing Science and Technology 31(1), 49-63.

Orlowski, K. A., Ochrymiuk, T., and Atkins, A. (2014). "An innovative approach to the forecasting of energetic effects while wood sawing," Drvna Industrija 65(4) 273-281. DOI: $10.5552 /$ drind.2014.1341

Orlowski, K. A., Sandak, J., and Dzurenda, L. (2006). "The effect of the wood temperature upon the specific cutting resistance during machining narrow-kerf saws," Annals of Warsaw Agricultural University Horticulture and Landscape Architecture 2006(59), 151-154.

Orlowski, K. A., Ochrymiuk, T., Hlaskova, L., Chuchala, D., and Kopecky, Z. (2020). "Revisiting the estimation of cutting power with different energetic methods while sawing soft and hard woods on the circular sawing machine: A Central European case," Wood Science and Technology (2020) 54:457-477.

Scholz, F., Duss, R., Hasslinger, R., and Ratnasingam, J. (2009). "Integrated model for the prediction of cutting forces," in: Proceedings of the $19^{\text {th }}$ International Wood Machining Seminar, Nanjing, China, pp. 183-190.

Siklienka, M., Argay, F., and Kminiak, R. (2012). "Impact of saw blade geometry on surface quality in transverse sawing of grown wood," in: Chip and Chipless Woodworking, Technical University in Zvolen, Zvolen, Slovakia, pp. 325-333. (In Slovak)

Siklienka, M., Kminiak, R., and Argay, F. (2013). "Effect of saw blade geometry on cutting performance in crosswise cutting of beechwood," Acta Facultatis Xylologiae Zvolen 55(1), 91-99. (In Slovak)

Siklienka, M., and Mišura, L. (2006). "Impact of chosen parameters on cutting performance by cutting circular saw," 
(http://www.tuzvo.sk/files/DF/katedry_df/kod/konferencia/2006/siklienka_misura.pdf), Accessed 20 Sept 2015. (In Slovak)

Siklienka, M., Kminiak, R., Šustek, J., and Jankech, A. (2017). Cutting and Processing Wood (Edition 1), Technical University in Zvolen, Zvolen, Slovakia. (In Slovak) STN ISO 3002-4 (1995). "Rezné nástroje. Základné veličiny pri rezaní a brúsení. 4. Čast': Sily, práca a výkon. [Cutting tools. Basic quantities in cutting and grinding. Part 4: Forces, energy and power]," Slovak Office of Standards, Metrology and Testing, Bratislava, Slovak Republic. (In Slovak)

Streklov, I. M. (2015). "Increasing saw blade durability for cross-cutting wood, lasertreated saw blade," (http://tekhnosfera.com/povyshenie-iznosostoykosti-kruglyh-pildlya-poperechnoy-raspilovki-drevesiny-metodom-lazernoy-termicheskoy-obrabotkizubi), Accessed 20 Sept 2015. (In Russian)

Suchanov, V. P. (1984). "Circular sawing machines," (http://www.booksite.ru/fulltext/rusles/suhan/text.pdf), Accessed 20 Sept 2015. (In Russian)

Svoreň, J. (2002). Wood Processing Machines. Part I. (Edition I), Technical University in Zvolen, Zvolen, Slovakia. (In Slovak)

Article submitted: May 14, 2020; Peer review completed: July 3, 2020; Revised version received: September 21, 2020; Accepted: December 10, 2020; Published: December 16, 2020.

DOI: 10.15376/biores.16.1.1029-1041 